\title{
Detailed reconstruction of gully headcut retreat using exposed tree roots: a case study from the Vsetínské vrchy Mts. (Outer Western Carpathians)
}

\author{
KAREL ŠILHÁN
}

University of Ostrava, Faculty of Science, Department of Physical Geography and Geoecology, Czechia; e-mail: Karel.Silhan@osu.cz

ABSTRACT Gully erosion is a widespread natural hazard that causes substantial financial losses every year. Dendrogeomorphic (tree ring-based) methods are a good alternative approach for assessing gully development in forested areas. The majority of previous dendrogeomorphic studies dealing with erosion focused on sheet erosion or erosion rates in the active channels of old, stabilized gullies. This study aims to asses newly originated gully development based on an analysis of exposed tree roots. Moreover, the root exposure data were used to calculate rates of linear and areal gully headcut retreat (GHR). In total, 81 samples (microcuts) from common spruce (Picea abies (L.) Karst) were analyzed for anatomical responses to root exposure. The existence of the shallow channel preceding the gully itself was identified. This GHR reconstruction (for a limited time period of eight years) provides evidence of highly active gully development in the forested area of the Flysch Carpathians that is comparable with results from semi-arid regions.

KEY WORDS gully - dendrogeomorphology - erosion rate - flysch - the Moravskoslezské Beskydy Mts.

ŠILHÁN, K. (2018): Detailed reconstruction of gully headcut retreat using exposed tree roots: a case study from the Vsetínské vrchy Mts. (Outer Western Carpathians). Geografie, 123, 2, 179-199.

Received March 2017, accepted March 2018.

CC Česká geografická společnost, z. s., 2018 


\section{Introduction}

Soil erosion is a widespread geomorphic process representing a potential natural hazard (Valentin, Poesen 2005). As anthropogenic, accelerated erosion can affect gentle, as well as steep, slopes in various climatic conditions (from arid to periglacial), it constitutes a global problem (Poessen et al. 2003). Soil erosion causes substantial damages primarily to agriculture. Sheet erosion decreases soil fertility and thickness of soil cover and can change physical (Bryan 2004) as well as chemical soil properties (Sanchis et al. 2008). Gully erosion decreases the area usable for agriculture and can damage infrastructure (Poesen et al. 2003). The sediments produced by soil erosion clog reservoirs (Poessen et al. 2003, Wasson et al. 2002) and decrease the navigability of rivers. In general terms, gully erosion could be one of the most dangerous types of soil erosion if it directly threated infrastructure (Ionita et al. 2015). The main drivers of gully erosion are topography, slope lithology, vegetation cover, land use and climatic conditions (Janeau et al. 2003; Li, Poesen, Valentin 2004; Avni 2005). Forested slopes are in general more protected against erosion processes due to increased infiltration rates. For this reason, anthropogenic activity is often the main driver of gully erosion in forested landscapes (Reid, Dune 1996; Nyssen et al. 2002). As changes in global climatic conditions are expected in the future, gully erosion intensity and extent will likely also change. Therefore, an understanding of past gully erosion is crucial for projecting future gully development. The development of past gully erosion was reconstructed using several approaches. Aerial orthophotos enable fast reconstruction over relatively large areas (Vandekerckhove, Poesen, Govers 2003). However, the accessibility and resolution of images, as well as dense vegetation cover, limit the accuracy or even feasibility of reconstruction from these images. Field monitoring using installation of erosion pins is a very accurate method (Sirvent et al. 1997). Unfortunately, this approach is very time consuming and applicable to only limited areas. The abovementioned limitations of these methods call for the development of alternative approaches for past gully erosion reconstruction.

Dendrogeomorphic methods have been successfully used for reconstruction of past events and assessment of geomorphic processes (Alestalo 1971). For example, tree ring-based methods enable reconstruction of the timing and spatial development of past debris flows (Strunk 1997; Bollschweiler et al. 2007; Šilhán 2012b; Tichavský, Šilhán 2015), rockfalls (Stoffel 2006, Šilhán, Pánek, Hradecký 2013; Trappmann, Corona, Stoffel 2013), landslides (Fantucci, Sorriso-Valvo 1999; Lopez Saez et al. 2012; Šilhán, Pánek, Hradecký 2012; Šilhán et al. 2013), and snow avalanches (Corona et al. 2010; Voiculescu, Onaca, 2013; Šilhán, Tichavský 2017). Soil erosion has often been reconstructed using dendrogeomorphic methods (Hitz et al. 2008; Malik 2008; Chartier, Rostagno, Roig 2009; Ballesteros et al. 2013; Rovéra 
et al. 2013). Nevertheless, most previous research has focused on sheet erosion, whereas gully erosion is rarely analysed. Much progress has been made during the last several decades in sheet erosion reconstruction. Previously unexamined tree species (Sun, Wang, Hong 2014) and even shrubs (Chartier, Rostagno, Roig 2009) have been successfully used for erosion rate determination. Corona et al. (2011) demonstrated that tree roots respond to decreased soil cover before actual root exposure. This finding was subsequently used for sheet erosion analysis (e.g., Ballesteros et al. 2013). Moreover, the results obtained with tree root analysis compare favourably with data from monitoring of erosion pins (Lopez Saez et al. 2011), and point data were successfully extrapolated to larger areas. On the other hand, gully erosion has rarely been studied using exposed tree roots. Gully erosion rates were reconstructed by Malik $(2006,2008)$ and Moravska, Wronska-Walach (2012), but these studies focused exclusively on the active floors of large, stabilized gullies. Stoffel et al. (2012), Bodoque et al. (2011), Chartier et al. (2016), Šilhán, Ružek, Burian (2016) and Šilhán et al. (2016) reconstructed erosion rates on the sides of gullies, but linear (i.e. the distance along the slope over which the gully head retreated per unit of time) and areal (areal expansion of the gully over time; Frankl et al. 2012; Vanmaercke et al. 2016) gully headcut retreat (GHR) were not determined. Vandekerckhove et al. (2001) described methods for GHR reconstruction using exposed tree roots in detail. Unfortunately, studies on detailed GHR determination using exposed tree roots are generally still lacking with exceptions of Vandekerckhove et al. (2001) or Ballesteros et al. (2017). This statement is especially true for new, fresh gullies that are a primary factor in the loss of usable land for agriculture or silviculture.

The Flysch Carpathians are among the areas in Europe that are most affected by gully erosion (Buzek 1999, Cerdan et al. 2010, Panagos et al. 2015). The slopes of the Flysch Carpathians are very prone to gully erosion in spite of dense forest cover (Buzek 1994, Šilhán 2012a). Gullying processes are frequently triggered by unsuitable anthropogenic interventions on slopes (forest roads, culverts, clearcuttings; Buzek 1998, 2000). Moreover, the underlying lithologies are rich in smectite clays (Pánek et al. 2010) that, together with high precipitation, increase susceptibility to erosion. Detailed GHR reconstruction has still not been performed in this area using dendrogeomorphic methods, although the gully drainage network is dense in places, and the tree species present in this region (Picea, Larix, Abies, and Fagus spp.) are very suitable for dendrogeomorphic analysis.

The aims of this study are i) to explore the potential of exposed tree roots for analysis of gully erosion in the Flysch Carpathians, ii) to reconstruct detailed development of a newly generated gully using dendrogeomorphic methods, and iii) to quantify gully headcut retreat rates based on the data from exposed tree roots. 


\section{Study area}

The area investigated in this study, which has suitable conditions for reconstructing gully development using dendrogeomorphic methods, lies in the Vsetínské vrchy Mountains (Czechia; $18^{\circ} 07^{\prime} \mathrm{E} ; 49^{\circ} 23^{\prime} \mathrm{N}$; Fig. 1). The mountains are of Tertiary age and are built up of flysch rocks, primarily claystones and mudstones interbedded with thin sandstones. Moreover, the rocks contain large amounts of smectite as a result of mineral weathering (Baroň et al. 2004). These lithological conditions in combination with the underlying nappe structure and the existence of fault zones, predispose the Vsetínské vrchy Mountains to various types of slope processes and mass movements (Baroň et al. 2004, Klimeš et al. 2009), including gully erosion (Šilhán 2012a). Mean annual precipitation is $1231 \mathrm{~mm}$, as measured at the Horní Bečva meteorological station, which is $10 \mathrm{~km}$ from the study site. Most of this precipitation falls in the warmer half of the year, and the mean annual temperature is $7.2^{\circ} \mathrm{C}$. The vegetation forest cover of the study area consists mainly of Norway spruce (Picea abies (L.) Karst.) and European beech (Fagus sylvatica L.).

The studied gully $\left(49^{\circ} 23^{\prime} \mathrm{N} ; 18^{\circ} 07^{\prime} \mathrm{E}\right)$ originated on the left bank of the Tísňavy stream (Fig. 1). The gully density in the surrounding of the study site is ca. $1.1 \mathrm{~km} \cdot \mathrm{km}^{-2}$. The gully is eroded into the adjacent slope, and has a length of ca. $8 \mathrm{~m}$. The depth of the gully decreases from ca. $3 \mathrm{~m}$ at the mouth to ca. $90 \mathrm{~cm}$ at the headcut. In plan view, the gully has the shape of an acute triangle with a width of ca. $5 \mathrm{~m}$ at the mouth. A shallow channel, at most $20 \mathrm{~cm}$ deep and with a length of ca. $18 \mathrm{~m}$, enters into the gully at the headcut. The channel starts below a forest road culvert, where the areal water flow is concentrated. Seven tree roots crossing this shallow channel were used for analysis of its development (channel roots). The position of the gully headcut itself is controlled by the presence of transverse $P$. abies roots that constitute a temporary hindrance to further gully propagation. The gully headcut is a ca. $90 \mathrm{~cm}$ high wall eroded in weathered sediments, with flysch rocks under these roots. The analysed gully segment was ca. $3 \mathrm{~m}$ long below the gully head. In this segment, 12 transverse tree roots occurred. Nine of these roots were used for detailed gully development analysis (gully roots).

\section{Methods}

\subsection{Field dendrogeomorphic approaches}

The chosen gully was geomorphically mapped to record the positions of the gully edge, neighbouring trees, the shallow channel, all visible tree roots, and other relevant features. The gully dimensions (length, width, and the perimeter shape) were surveyed geodetically in local coordinate system only once - before the 

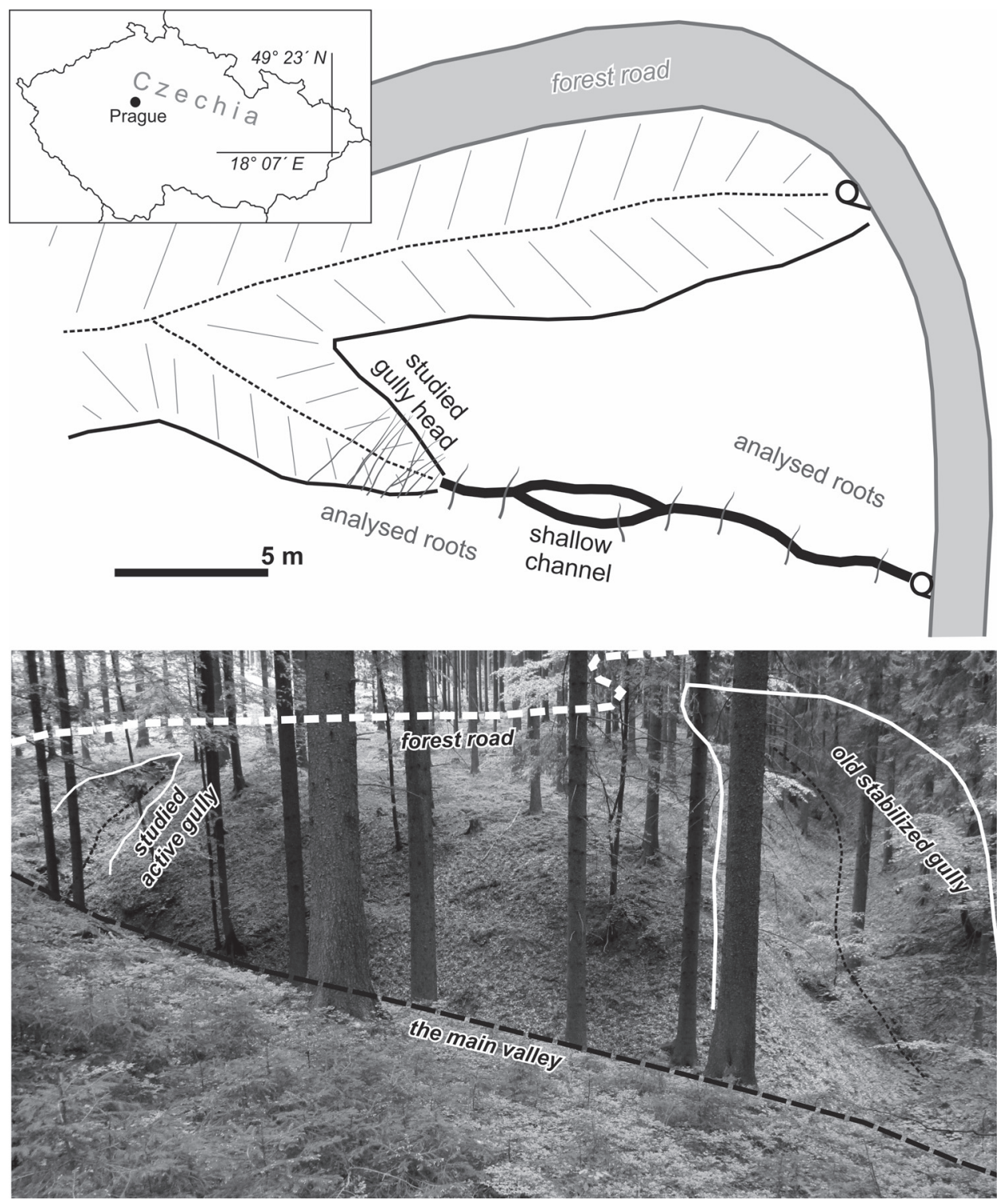

Fig. 1 - The location of the study site (A), a map of the gully and its surroundings (B), and a photo showing an overview of the broader gully area (C).

sampling. The position of each studied transverse root was recorded, and root parameters (please see next) were measured with $1 \mathrm{~cm}$ accuracy by tape. Two groups of tree roots were sampled. One group contained roots crossing the gully itself (gully roots) and another group contained roots exposed in the shallow 


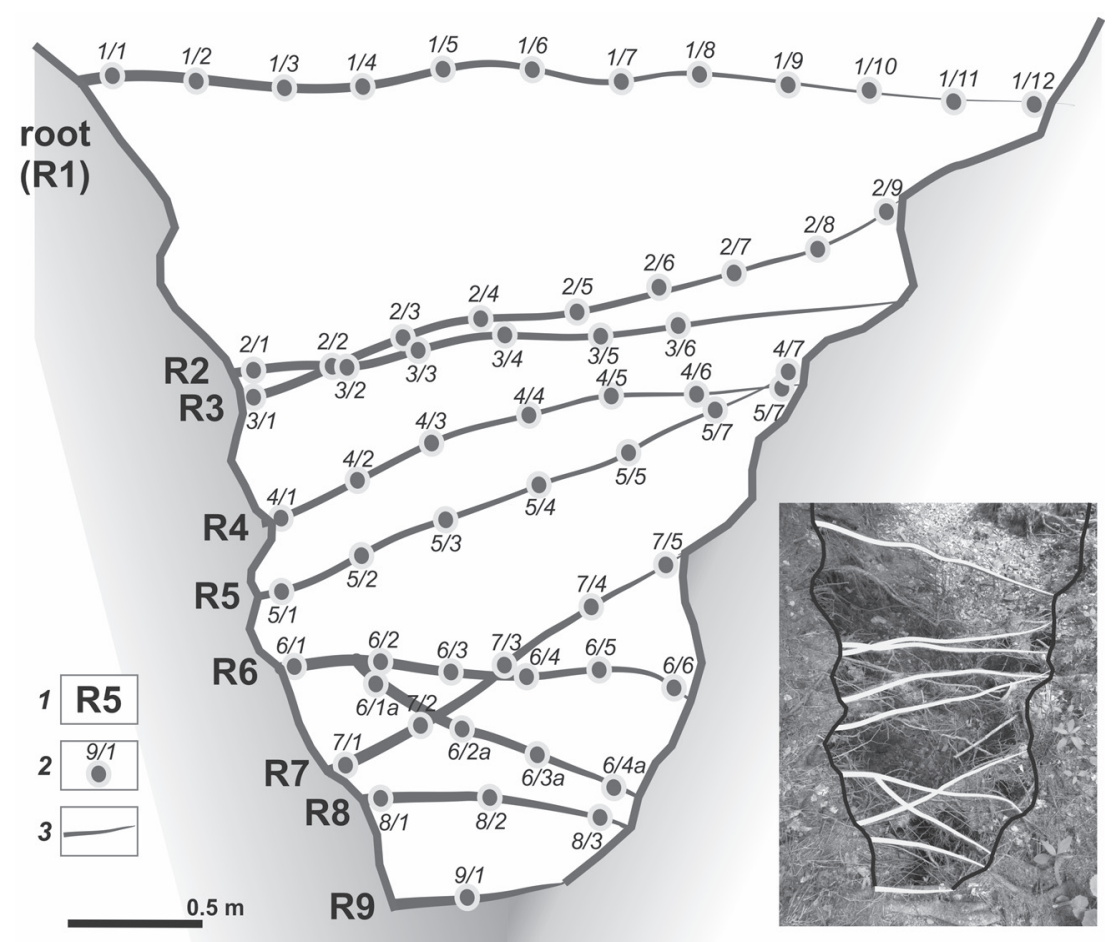

Fig. 2 - The positions of analyzed roots crossing the gully head and the locations of individual samples ( 1 - the root number, 2 - the sample position, 3 - root).

channel located above the gully head (channel roots). This approach was selected due to supposed different mechanism of root exposure (abrupt exposure in the case of gully roots vs. gradual exposure in the case of channel roots). The measured parameters (by tape with $1 \mathrm{~cm}$ precision) and recorded for each studied root were the root length, the distance from each root end to the gully head, and the height of the root above the gully floor (this parameter was measured every $10 \mathrm{~cm}$ along each root's length). The vertical distance from the channel floor and the distance from the gully head were measured for all analysed roots in the shallow channel located above the gully head. Sampling of tree roots was done by handsaw. Samples (approximately $2 \mathrm{~cm}$ in length) were extracted at $10 \mathrm{~cm}$ intervals along each transverse root (Fig. 2). The nearest tree was located $1.7 \mathrm{~m}$ from the gully's edge. For this reason, all tree roots could be sampled over their full lengths. Is such distances from tree stem (in general more than $1 \mathrm{~m}$; Stoffel et al. 2013) the effect of vertical tree stem movements during tree growth and corresponding anatomical reactions in the root that are not caused by gully incision can be excluded. Only living tree roots were sampled. 


\subsection{Laboratory dendrogeomorphic approaches}

All samples were air dried for several weeks. The analysis of samples followed the approach presented by Corona et al. (2011). Each sample was divided into two ca. $1 \mathrm{~cm}$ wide discs. The discs were sanded (up to 1,000 grit) to enable good visibility of individual tree rings. The widths of tree rings on the first disc were measured using a TimeTable dendrochronological measuring device (VIAS 2005) and PAST4 software under binocular stereoscopic microscope. Tree ring widths were measured on several (4-5) radii per disc. Individual increment curves from measured values were subsequently cross-dated to minimize the possibility of incorrect dating due to false, missing or wedge rings (Morawska, Wronska-Walach 2012). As the lengths of tree ring series were limited, only visual cross-dating was possible. The second disc in each pair was prepared for microsectioning. Disc was split into smaller pieces and a $15 \mu \mathrm{m}$-thick slice was cut using a G.S.L.1 microtome (Gärtner 2007). The microcut was stained with safranin and Astra blue, dehydrated with alcohol mixtures (50, 70, and $96 \%$ alcohol), rinsed with Diasolv and fixed in Canada balsam (Schweingruber 1978).

The identification of the timing of root exposure was determined from the analysis of woody cells. Microsections were photographed at $50 \times$ magnification with a precision of $1 \mu \mathrm{m}$. The images of permanent sections (microcuts) were analysed using WinCELL Reg software. As the most important anatomical reaction of coniferous trees to root exposure is a significant (ca. $50 \%$ ) decrease in the cell lumen area of early earlywood (Gärtner, Schweingruber, Dikau 2001), the parameter of early earlywood cells (lumen area) was measured for 12 cells per tree ring, as recommended by Rubiales et al. (2008), Corona et al. (2011), or Lopez Saez et al. (2011). The significance of changes in the mean cell lumen size of each pair of adjacent root rings was assessed using the Mann-Whitney test. Moreover, the occurrence of reaction (compression) wood was analysed macroscopically. Reaction wood is known to be a growth response to mechanical stresses that can be induced e.g. by decreasing soil cover and changing temperature, moisture and pressure conditions during root growth (Corona et al. 2011). Potential signs of root exposure, such as the proportion of latewood and the root ring widths, were also examined (Fig. 3).

\subsection{Gully headcut retreat rate reconstruction}

The years of exposure were determined for each root sample. The coordinates of each sample were placed into a geographical information system (ArcGIS 9.2 software; ESRI 2005) as point data associated with the number of years of exposure. Based on these data, the gully development was reconstructed. The linear 


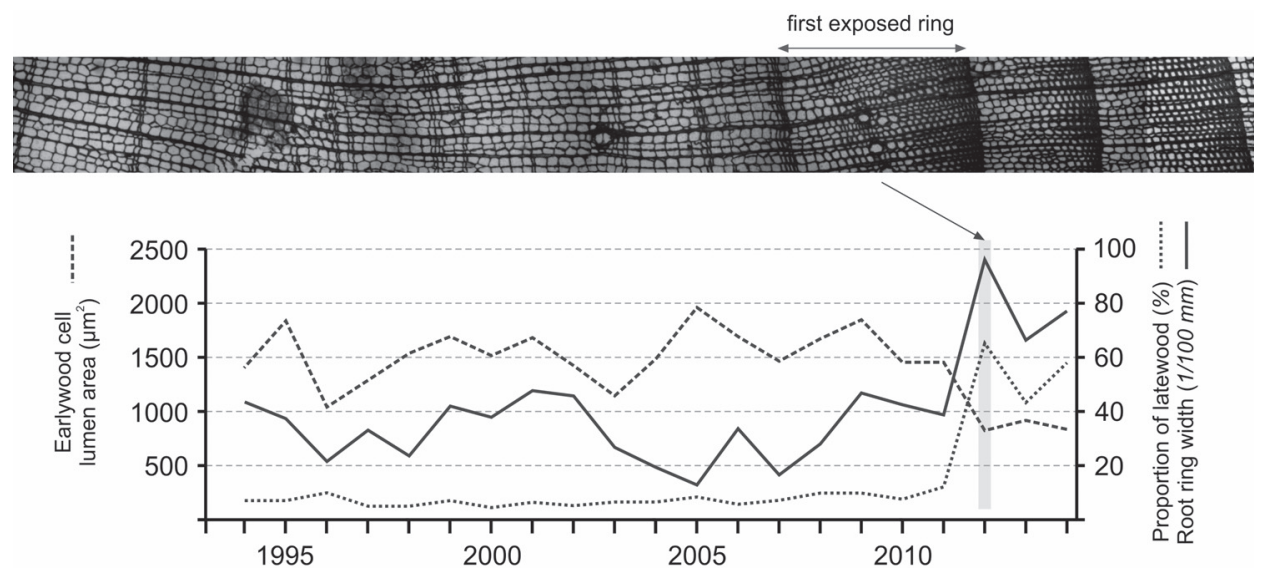

Fig. 3 - The anatomical reactions of roots to exposure, including the increase in the early earlywood cell lumen area, the increase in the proportion of latewood in root ring, and the increase in the root ring width.

and areal GHR was calculated using ArcGIS' Spatial Analysis toolbox with $1 \mathrm{~cm}$ and $10 \mathrm{~cm}^{2}$ accuracy, respectively. The volumetric GHR estimation would suffer from an unreasonably large degree of uncertainty, and so it was not calculated.

\section{Results}

\subsection{Sample number and age; anatomical reactions}

In total, nine living transverse roots were analysed in the top segment of the gully, and seven roots crossing the shallow channel were analysed. Sixty samples were extracted from nine gully roots (roots that crossed the gully; Fig. 4), and 21 samples were extracted from seven channel roots (roots that crossed the channel). A maximum of 12 samples were extracted from one root. On average, 6.7 samples were extracted per gully root. Three samples were extracted from each channel root. The mean age of all roots was 26.7 years (stdev: 8.8 years). In general, the gully roots were older (mean age: 29.8 years; stdev: 9.2 years) than the channel roots (mean age: 22.7 years; stdev: 6.8 years). The oldest sample contained 48 root rings, and the youngest sample contained only 16 root rings.

In total, 81 microsections were prepared and analysed. The abrupt decrease in the early earlywood cells lumen area was identified in most samples. This anatomical reaction was present in all samples that were exposed after 2008. In samples exposed before this year, the decrease in lumen area was not always abrupt and statistically significant. Moreover, samples exposed before 2008 frequently 

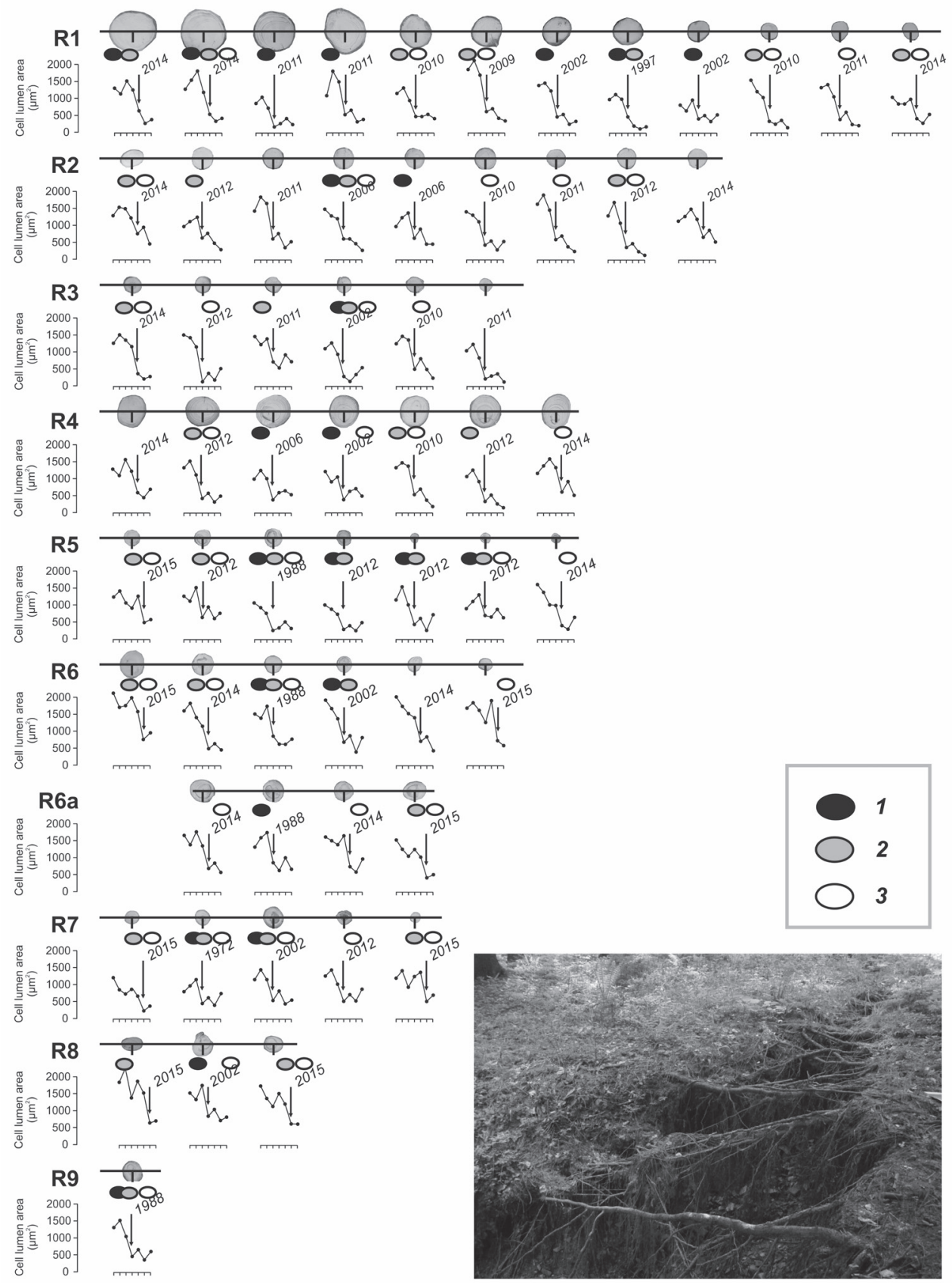

Fig. 4 - The anatomical (mean early earlywood cell lumen area) and macroscopical analysis of all samples from the gully roots ( 1 - reaction wood, 2 - abrupt growth increase, 3 - increase of the latewood proportion), and the picture of the studied gully head. 
contained reaction wood (80.2\%). In contrast, reaction wood occurred only in $22.2 \%$ of samples with exposure after 2008 . The root ring widths increased in the exposure year in $61.7 \%$ of all samples, whereas the proportion of latewood increased in the exposure year in $76.5 \%$ of all samples.

\subsection{Spatio-temporal development of roots exposure}

The root samples recorded exposure events in ten distinct years, 1977, 1988, 1997, 2002, 2006, 2010, 2011, 2012, 2014, and 2015. These data yield a mean interval between erosion events of 3.9 years. Interestingly, roots crossing the shallow channel revealed in general older exposure age in comparison with the roots crossing the gully head. The channel roots were exposed in 1988, 1997, 2002, 2006 and 2010 , whereas the gully roots were exposed in all ten mentioned years. The gully roots were exposed before 2009 near the middle of the gully. On the other hand, the root samples collected from near the gully sides were exposed much later (all after 2009). Moreover, the number of years since root exposure decreases
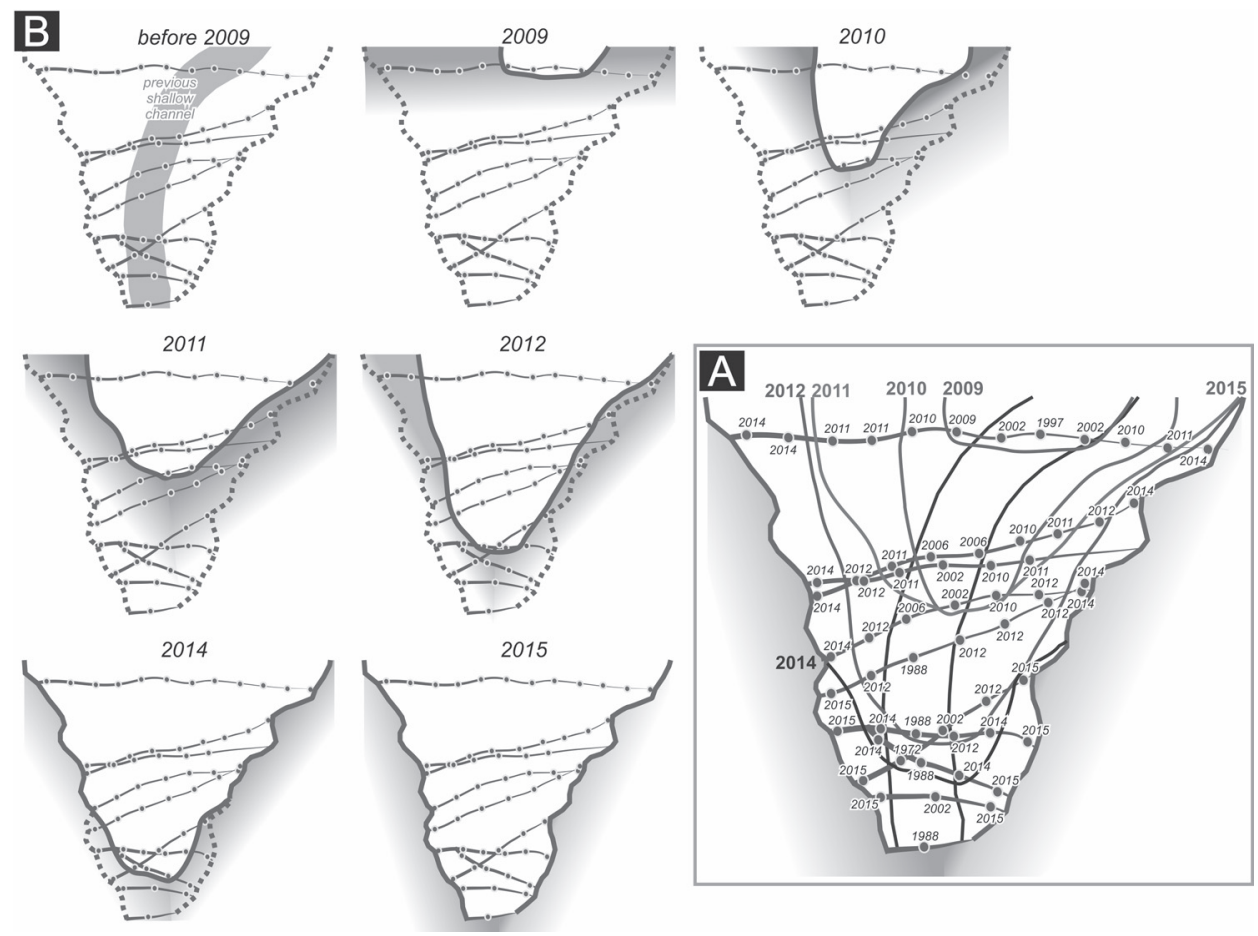

Fig. 5 - The development of the gully horizontal projection as reconstructed from tree root exposure. 
with decreasing distance to the gully edge (Fig. 5A). These results suggest that the studied gully segment grew episodically, in six distinct years (Fig. 5B). The roots crossing the shallow channel were between 2 and $17 \mathrm{~cm}$ above the channel floor. The channel incision rate values were calculated to be from 0.6 to $1.4 \mathrm{~cm} \cdot$ year $^{-1}$ (Table 1). The channel roots near the gully head revealed generally older exposure years $(1988,1997$, and 2002) than the roots that were further from the gully head (2006 and 2010). Calculated values of vertical channel incision rates generally decrease with increasing distance from the gully head (Table 1).

\subsection{Gully headcut retreat rate}

The total linear gully retreat was $274 \mathrm{~cm}$ since 2010 (that is, $39 \mathrm{~cm} \cdot$ year $^{-1}$ ). The largest single-year gully headcut retreat occurred in 2010, when the headcut retreated $112 \mathrm{~cm}$. In contrast, the gully head retreated only $27 \mathrm{~cm}$ in 2014 . The gully head did not move in 2013 , and in 2011, the gully became wider without any

Table 1 - Overview of sampled channel roots exposure, and calculated rates of channel incision.

\begin{tabular}{lcccc}
\hline Root ID & $\begin{array}{c}\text { Distance from the road } \\
(\mathrm{m})\end{array}$ & $\begin{array}{c}\text { Distance from gully floor } \\
(\mathrm{cm})\end{array}$ & $\begin{array}{c}\text { Year of root } \\
\text { exposure }\end{array}$ & $\begin{array}{c}\text { Channel incision rate } \\
\left(\mathrm{cm}_{\text {.year }}{ }^{-1}\right)\end{array}$ \\
\hline C1 & 5 & 10 & 1997 & 0.5 \\
C2 & 7 & 15 & 2002 & 1.1 \\
C3 & 9 & 17 & 1988 & 0.6 \\
C4 & 11 & 14 & 2006 & 1.4 \\
C5 & 13 & 8 & 2010 & 1.3 \\
C6 & 19 & 2 & 2010 & 0.3 \\
C7 & 21 & 14 & 2006 & 1.4 \\
\hline
\end{tabular}

Table 2 - The values of linear and areal gully headcut retreat (GHR), and values of gully widening in cross sections with various distance from gully head

\begin{tabular}{|c|c|c|c|c|c|c|c|c|c|}
\hline \multirow[t]{2}{*}{ Year } & \multirow{2}{*}{$\begin{array}{c}\text { Areal GHR } \\
\left(\mathrm{m}^{2}\right)\end{array}$} & \multirow{2}{*}{$\begin{array}{l}\text { Cumulative } \\
\text { areal GHR } \\
\left(\mathrm{m}^{2}\right)\end{array}$} & \multirow{2}{*}{$\begin{array}{l}\text { Linear } \\
\text { GHR }(\mathrm{cm})\end{array}$} & \multirow{2}{*}{$\begin{array}{c}\text { Cumulative } \\
\text { linear } \\
\text { GHR }(\mathrm{cm})\end{array}$} & \multicolumn{5}{|c|}{ Gully widening $(\mathrm{cm})$} \\
\hline & & & & & $\begin{array}{c}2.5 \mathrm{~m} \\
\text { from head }\end{array}$ & $\begin{array}{c}2.0 \mathrm{~m} \\
\text { from head }\end{array}$ & $\begin{array}{c}1.5 \mathrm{~m} \\
\text { from head }\end{array}$ & $\begin{array}{l}1.0 \mathrm{~m} \\
\text { from head }\end{array}$ & $\begin{array}{c}0.5 \mathrm{~m} \\
\text { from head }\end{array}$ \\
\hline 2010 & 1.09 & 1.09 & 112 & 112 & 69 & 90 & 43 & $x$ & $x$ \\
\hline 2011 & 0.63 & 1.71 & 0 & 112 & 76 & 56 & 14 & $x$ & $\times$ \\
\hline 2012 & 1.35 & 3.06 & 88 & 200 & 19 & 39 & 79 & 97 & $\times$ \\
\hline 2013 & 0.00 & 3.06 & 0 & 200 & 0 & 0 & 0 & 0 & 0 \\
\hline 2014 & 1.10 & 4.17 & 27 & 227 & 64 & 69 & 40 & 20 & 74 \\
\hline 2015 & 0.74 & 4.91 & 47 & 274 & 0 & 0 & 0 & 26 & 56 \\
\hline
\end{tabular}

Note: $x$ - the gully head did not reach the cross section in a given year. 


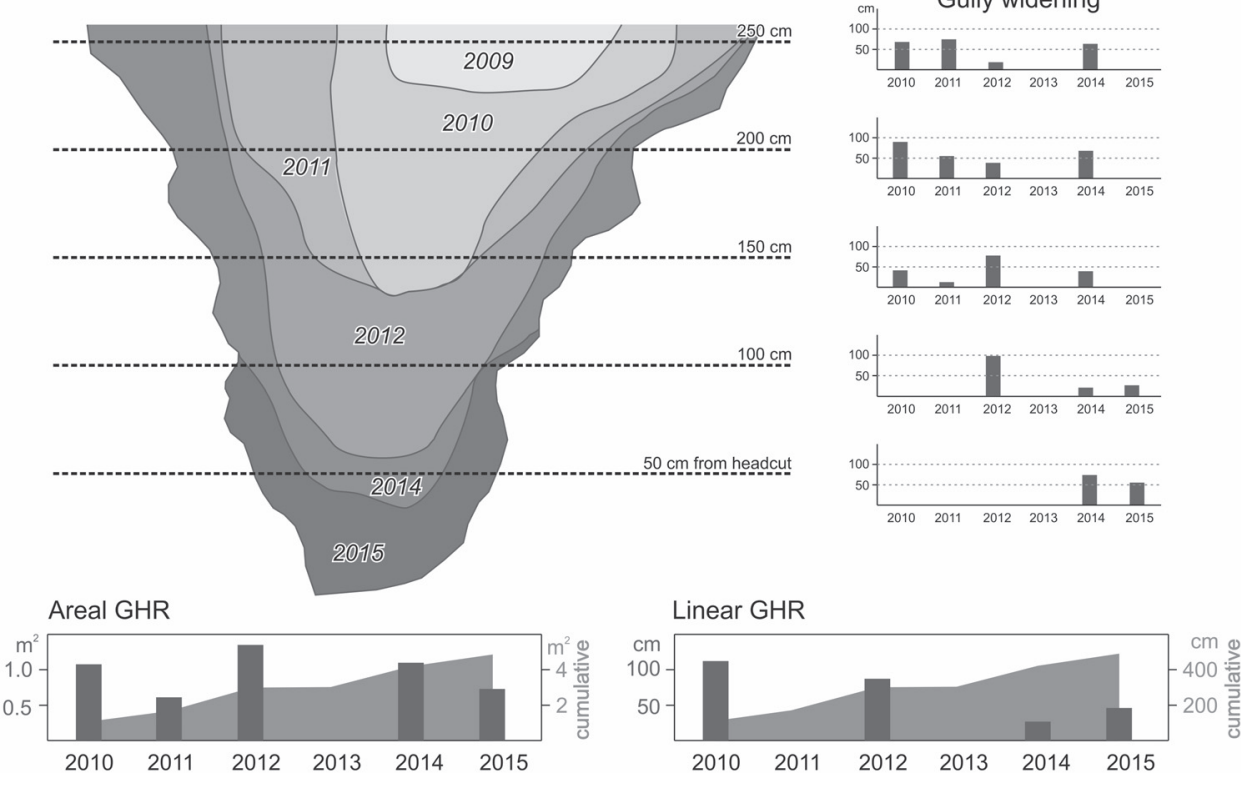

Fig. 6 - The reconstruction of linear and areal gully headcut retreat (GHR) rates, and the gully widening in various cross sections.

elongation (Table 2, Fig. 6). Gully widening was calculated in five cross sections in $0.5 \mathrm{~m}$ steps from the gully head (Fig. 6). Various patterns of gully growth occurred in various years. For example, the gully widened more with decreasing distance to gully head in 2012. However, in 2011, gully widening decreased with decreasing distance to gully head (Fig. 6).

The total areal GHR in the studied gully segment was calculated as $4.91 \mathrm{~m}^{2}$. The most important erosion event impacting the areal GHR occurred in $2012\left(1.35 \mathrm{~m}^{2}\right)$. Although the linear GHR was zero in 2011, the areal GHR was $0.63 \mathrm{~m}^{2}$ due to gully widening. The last dated erosion event (AD 2015) led to an increase in gully area of approximately $0.74 \mathrm{~m}^{2}$. It was the second lowest calculated areal GHR (Table 2).

\section{Discussion}

The development of the selected gully segment was reconstructed in detail using microscopic analysis of exposed tree roots. The analysis of a dense net of samples (on average, 12.1 samples per $\mathrm{m}^{2}$ ) allowed us to characterize the gully's development since 2009. Moreover, this represents the first time that gully headcut retreat rates were calculated based on root exposure data in a newly originated gully. 


\subsection{The potential of exposed P. abies roots for reconstructing gully erosion}

Exposed roots of $P$. abies were previously used for analysis of erosion processes several times. For example, Hitz et al. (2008), Malik (2008) and Malik, Matyja (2008) used exposed $P$. abies roots for reconstruction of erosion rates on gully sides or river banks. Abrupt decrease in the early earlywood cell lumen area agrees with the findings of Gärtner (2007) and Malik (2008), who attributed this type of reaction to abrupt exposure of tree roots. P. abies roots react to changes in edaphic temperature and humidity, as well as soil pressure. Smaller woody cells are more resistant to the development of ice crystals and air bubbles and associated embolisms. Higher numbers of cells in wide post-exposure rings helps ensure that exposed roots can still participate in the plant's circulation (Schweingruber 1978). As only early wood cells changes are standardly used as an evidence of root exposure, potential shift in dating occur if root exposure occur during the summer or autumn. In this case, other evidences of root exposure (changes in ring width or reaction wood) is suitable use for dating precision. Abrupt (and statistically significant) changes in cell size were visible particularly in the marginal parts of tree roots that had been exposed most recently. This result suggests that the parts of roots in the middle part of the gully were exposed rapidly. In contrast, most of the samples from roots crossing the shallow channel do not display an abrupt decrease in the cell lumen size, and moreover, reaction wood occurred frequently in these samples. This anatomical behaviour is similar to the anatomical response of Scots pine roots (Pinus sylvestris L.) to decreasing the soil cover to less than $30 \mathrm{~mm}$ (Corona et al. 2011). As the material of weathered flysch rocks has a slightly different grain size distribution and density compared with the porous material investigated by Corona et al. (2011), we expect that changes in soil cover thickness will cause growth responses that are more or less similar to, those reported by Corona et al. (2011). Such reactions, regarding the new findings by Corona et al. (2011), Ballesteros et al. (2013) and Bodoque et al. (2015), can be explained given that the roots cross the channel. Partially exposed roots can cause channel blockage and prevent sediment movement (Stoffel et al. 2013). The sediments accumulate above the root, increasing the material pressure on it and producing conditions that are similar to those prior to root exposure. In such cases, the anatomical reaction in P. abies is gradual, and reaction wood can develop, just as it does in P. sylvestris.

\subsection{The interpretation of exposure data regarding development of erosion forms}

These findings have an important impact on the interpretation of our results, as well as optimal sampling strategies for future gully erosion studies. Because the 
middle parts of transversal gully roots were exposed gradually, as were roots crossing the shallow channel, it seems likely that the gully occupies the same general course as the original shallow channel. Only limited lengths of the tree roots were exposed in each event, and these roots could constitute small dams for sediment. The other roots were exposed totally and rapidly during individual events of gully headcut retreat. This conclusion is supported by abrupt and significant anatomical reactions in root rings (Fig. 7A). Thus, for reconstruction of real gully headcut retreat using data from exposed tree roots, it is necessary to take several samples (in various positions of root length) from each root crossing the gully. Sampling and analysing only the middle part of the root, as used by several authors in past (e.g., Malik 2006, 2008; sampling for the analysis of active gully floor development) could introduce substantial errors in gully erosion reconstructions because the incision of original shallow channel or rill could be dated instead of incision of the actual gully. On the other hand, if the possible damming effect of roots crossing shallow channel and the pre-exposure anatomical reactions are considered, the data from such roots can be used for the reconstruction of channel incision rates. Roots crossing the shallow channel can even constitute baseline local erosion (Fig. 7B). Sedimentation rates increase above these roots, whereas vertical erosion is very common below such roots due to water cascading over the root. The result of this process is an unbalanced longitudinal channel profile with micro step-pool morphology (Montgomery, Buffington 1997). This fact can influence reconstructed incision rates based on root exposure data.

The relationship between the distance from the gully head and rates of gully widening can be caused by the presence of transverse roots in the gully head. These roots can stabilize the gully head and temporarily interrupt gully retreat (Vannoppen et al. 2015). In such cases, widening can occur even without any gully elongation (Fig. 6).

\subsection{The intensity of gully development}

Based on the root exposure data and the nature and intensity of anatomical reactions, a theoretical model of gully development was built. As the obtained data about the chronological gully development cover only limited time period (eight years: 2009-2016) the created model can be valid just for limited period of gully existence (period of active gully elongation). The present-day gully probably follows the course of the pre-existing shallow channel that connects to the gully head. The gully itself developed episodically, by gully headcut retreat. These erosion pulses appear to stop when they encounter transverse roots. Water cascading over these obstructing roots next shapes the steepness of the gully head wall below which a plunge pool may develop (Poesen et al. 2002). The root scouring by water 

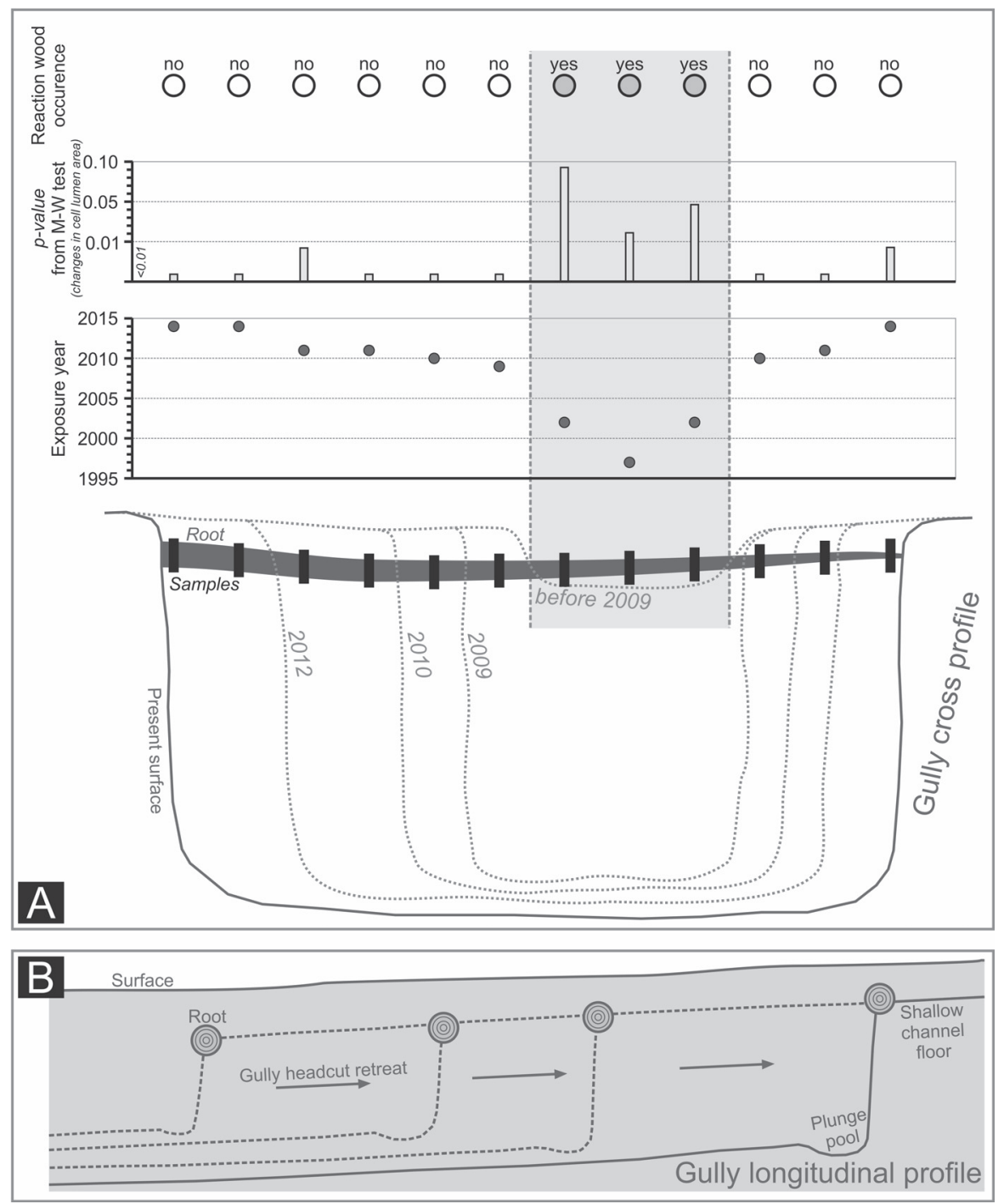

Fig. 7 - The gully cross section development based on the root exposure data (A), and the principle of longitudinal profile development.

eventually precede the next erosion event. In general, the gully development is very rapid thereafter. The gully head wall in smectite rocks is unstable, and in combination with frequent extreme precipitation events in the Flysch Carpathians (Brázdil, Kirchner 2007), mean rates of retreat may reach several tens of centimetres per year (mean $39 \mathrm{~cm} \cdot$ year $^{-1}$ in this case). Melting water from fast spring snowmelt can play an important role in gully development, nevertheless the role 
of this potential trigger is rather minor in the study area (Šilhán, 2012a). In contrast, the main triggers of gully erosion are short duration (less than 24 hours) above-average (even more than $100 \mathrm{~mm}$ ) precipitation totals in the study region. The reconstructed values of GHR in this study are comparable with those from highly erosive environments in the semi-arid regions of Spain (up $51 \mathrm{~cm} \cdot y^{-1} \mathrm{r}^{-1}$ ), Morocco (31 cm $\cdot$ year $^{-1}$ ) (Marzolff, Ries 2007), and Ethiopia (34 cm $\cdot$ year $^{-1}$; Frankl et al. 2012).

As the gully head wall is practically vertical, the gully floor is very uneven, and P. abies roots grow just below the soil surface, the calculation of volumetric GHR was not possible using the dendrogeomorphic approach. This limitation could be overcome at study sites where tree species with deep roots occur.

\section{Conclusions}

Exposed tree roots were used in this study to reconstruct the linear and areal gully headcut retreat rates (GHR) of a fresh, newly originated gully. In total, microscopic analysis of 60 samples (microsections) from nine living roots that extended all the way across the gully head revealed six erosion events since 2009 when the gully horizontal projection was changed. A shallow channel emptying into the gully in an upslope direction was analysed using 21 microsections of seven crossing roots. The channel yielded a longer record of erosion (since 1977) that reflected less dynamical development $\left(0.9 \mathrm{~cm} \cdot\right.$ year $^{-1}$ of vertical incision, on average), compared to the gully.

The main signs of root exposure were a decrease in early earlywood lumen area, an increase in the proportion of latewood in tree ring width, and an increase in tree ring width. Roots crossing the shallow channel displayed similar anatomical reactions to roots exposed by sheet erosion, probably due to their ability to temporarily dam the channel. Moreover, this study yields important findings and recommendations for future sampling strategies. Gullies are usually preceded by shallow channels, and the development of these shallow channels is recorded within locally exposed parts of tree roots. Gully headcut retreat exposes the rest of the roots abruptly, so the anatomical reaction in the parts of tree roots near the margins of gullies are different from the reactions of the middle parts of the roots. For this reason, roots crossing gullies should be sampled in several positions to differentiate the effects of the original shallow channel from subsequent gully headcut retreat. In contrast, previous studies recommended sampling only the middle of each gully-crossing root.

The approach described here enabled detailed reconstruction of linear and areal GHR in the forested area of mountains underlain by weak sedimentary rocks with important anthropogenic influences. The values were surprisingly similar to GHR 
rates in semi-arid environments. These findings correspond with reconstruction of erosion rates in the close neighbourhood of studied locality, and support the general assumptions about high activity of gully erosion in the wider region. This suggests that additional dendrogeomorphic (tree ring-based) research is necessary for assessing gully erosion activity in forested areas that do not have a history of systematic gully monitoring.

\section{References}

ALESTALO, J. (1971): Dendrochronological interpretation of geomorphic processes. Fennia, 105, 1-139.

AVNI, Y. (2005): Gully incision as a key factor in desertification in an arid environment, the Negev highlands, Israel. Catena, 63, 185-220.

BALLESTEROS, J.A., BODOQUE, J.M., LUCÍA, A., MARTÍN-DUQUE, J.F., DÍEZ-HERRERO, A., RUIZ-VILLANUEVA, V., RUBIALES, J.M., GENOVA, M. (2013): Dendrogeomorpholgy in Badlands: Methods, case studies and prospects. Catena, 106, 113-122.

BALLESTEROS, J.A., STOFFEL, M., MARTÍN-DUQUE, J.F., CORONA, C., LUCIA, A., BODOQUE, J.M., MONTGOMERY, D.R. (2017): Gully evolution and geomorphic adjustments of badlands to reforestation. Nature Scientific Report.

BAROŇ, I., CÍLEK, V., KREJČÍ, O., MELICHAR, R., HUBATKA, F. (2004): Structure and dynamics of deep-seated slope failures in the Magura Flysch Nappe, outer Western Carpathians (Czech Republic). Natural Hazards and Earth System Sciences, 4, 549-562.

BODOQUE, J.M., LUCÍA, A., BALLESTEROS, J.A., MARTÍN-DUQUE, J.F., RUBIALES, J.M., GENOVA, M. (2011): Measuring medium-term sheet erosion in gullies from trees: a case study using dendrogeomorphological analysis of exposed pine roots in central Iberia. Geomorphology, 134, 417-425.

BODOQUE, J.M., BALLESTEROS, J.A., LUCÍA, A., DÍEZ-HERRERO, A., MARTÍN-DUQUE, J.F. (2015): Source of error and uncertainty in sheet erosion rates estimated from dendrogeomorphology. - Earth Surface Processes and Landforms, 40, 1146-1157.

BOLLSCHWEILER, M., STOFFEL, M., EHMISCH, M., MONBARON, M. (2007): Reconstructing spatio-temporal patterns of debris-flow activity using dendrogeomorphological methods. Geomorphology, 87, 337-351.

BRÁZDIL, R., KIRCHNER, K. (2007): Vybrané přírodní extrémy a jejich dopady na Moravě a ve Slezsku. Masarykova univerzita, Český hydrometeorologický ústav, Ústav Geoniky Akademie Věd České republiky, v.v.i., Brno, Praha, Ostrava.

BRYAN, R.B. (2004): Gully-scale implications of rill network and confluence processes. In: Li, Y., Poesen, J., Valentin, C. (eds.): Gully Erosion Under Global Change. Sichuan Science and Technology Press, Chengdu, China, 73-95.

BUZEK, L. (1994): Eroze lesní půdy v povodí horní Ostravice. Zpravodaj Beskydy, 89-94.

BUZEK, L. (1998): Eroze lesní půdy v Moravskoslezských Beskydech. Veronica, 12, 40-41.

BUZEK, L. (1999): Water erosion of the forested area in the central part of the Moravskoslezské Beskydy Mts. - north-eastern part of the Czech Republic. In: Modern nature use and anthropogenic processes. Russian Academy of Sciences, University of Silesia, Irkutsk-Sosnowiec, 18-28.

BUZEK, L. (2000): Eroze lesní půdy při vyšších vodních srážkách a tání sněhové pokrývky. Geografie - Sborník České geografické společnosti, 105, 317-332. 
CERDAN, O., GOVERS, G., LE BISSONNAIS, Y., VAN OOST, K., POESEN, J., SABY, N., GOBIN, A., VACCA, A., QUINTON, J., AUERSWALD, K., KLIK, A., KWAAD, F. J. P. M., RACLOT, D., IONITA, I., REJMAN, J., ROUSSEVA, S., MUXART, T., ROXO, M. J., DOSTAL, T. (2010): Rates and spatial variations of soil erosion in Europe: A study based on erosion plot data. Geomorphology, 122, 167-177.

CHARTIER, M.P., ROSTAGNO, C.M., ROIG, F.A. (2009): Soil erosion rates in rangelands of northeastern Patagonia: A dendrogeomorphological analysis using exposed shrub roots. Geomorphology, 106, 344-351.

CHARTIER, M.P., GIANTOMASI, M.A., RENISON, D., ROIG, F.A. (2016): Exposed roots as indicators of geomorphic processes: A case-study from Polylepis mountain woodlands of Central Argentina. Dendrochronologia, 37, 57-63.

CORONA, CH., ROVÉRA, G., LOPEZ SAEZ, J., STOFFEL, M., PERFETTINI, P. (2010): Spatiotemporal reconstruction of snow avalanche activity using tree rings: Pierres Jean Jeanne avalanche talus, Massif de l'Oisans, France. Catena, 83, 107-118.

CORONA, C., LOPEZ SAEZ, J., ROVÉRA, G., STOFFEL, M., ASTRADE, L., BERGER, F. (2011): High resolution, quantitative reconstruction of erosion rates based on anatomical changes in exposed roots at Draix, Alpes de Haute-Provence - critical review of existing approaches and independent quality control of results. Geomorphology, 125, 433-444.

ESRI (2005): ArcGIS 9.2. Redlands, CA.

FANTUCCI, R., SORRISO-VALVO, M. (1999): Dendrogeomorphological analysis of a slope near Lago, Calabria (Italy). Geomorphology, 30, 165-174.

FRANKL, A., POESEN, J., DECKERS, J., HAILE, M., NYSSEN, J. (2012): Gully head retreat rates in the semi-arid highlands of Northern Ethiopia. Geomorphology, 173-174, 185-195.

GÄRTNER, H. (2007): Tree roots - Methodological review and new development in dating and quantifying erosive processes. Geomorphology, 86, 243-251.

GÄRTNER, H., SCHWEINGRUBER, F. H., DIKAU, R. (2001): Determination of erosion rates by analyzing structural changes in the growth pattern of exposed roots. Dendrochronologia, 19, 81-91.

HITZ, O.M., GÄRTNER, H., HEINRICH, I., MONBARON, M. (2008): Application of ash (Fraxinus excelsior L.) roots to determine erosion rates in mountain torrents. Catena, 72, 248-258.

IONITA, I., FULLEN, M.A., ZGŁOBICKI, W., POESSEN, J. (2015): Gully erosion as a natural and human-induced hazard. Natural Hazards, 79, 1-5.

JANEAU, J.L., BRICQUET, J.P., PLANCHON, O., VALENTIN, C. (2003): Soil crusting and infiltration on steep slopes in northern Thailand. European Journal of Soil Science, 54, 543-554.

KLIMEŠ, J., BAROŇ, I., PÁNEK, T., KOSAČÍK, T., BURDA, J., KRESTA, F., HRADECKÝ, J. (2009): Investigation of recent catastrophic landslides in the flysch belt of Outer Western Carpathians (Czech Republic): progress towards better hazard assessment. Natural Hazards and Earth System Sciences, 9, 119-128.

LI, Y., POESEN, J., VALENTIN, C. (2004): Gully Erosion Under Global Change. Sichuan Science Technology Press, Chengu, China. $354 \mathrm{pp}$.

LOPEZ SAEZ, J., CORONA, C., STOFFEL, M., ROVÉRA, G., ASTRADE, L., BERGER, F. (2011): Mapping of erosion rates in marly badlands based on anatomical changes in exposed roots and LiDAR data. - Earth Surface Processes and Landforms, 36, 1162-1171.

LOPEZ SAEZ, J., CORONO, C., STOFFEL, M., ASTRADE, L., BERGER, F., MALET, J.P. (2012): Dendrogeomorphic reconstruction of past landslide reactivation with seasonal precision: Bois Noir landslide, southern French Alps. Landslides, 9, 189-203. 
MALIK, I. (2006): Gully erosion dating by means of anatomical changes in exposed roots (Proboszczowicka Plateau, Southern Poland). Geochronometria, 25, 57-66.

MALIK, I. (2008): Dating of small gully formation and establishing erosion rates in old gullies under forest by means of anatomical changes in exposed tree roots (Southern Poland). Geomorphology, 93, 421-436.

MALIK, I., MATYJA, M. (2008): Bank erosion history of a mountain stream determined by means of anatomical changes in exposed tree roots over the last 100 years (Bílá Opava River Czech Republic). Geomorphology, 98, 126-142.

MARZOLFF, I., RIES, J.B. (2007): Gully erosion in semi-arid landscapes. - Zeitschrift für Geomorphologie, 51, 405-425.

MONTGOMERY, D.R., BUFFINGTON, J.M. (1997): Channel-reach morphology in mountain drainage basins. Geological Society American Bulletin, 109, 596-611.

MORAWSKA, M., WRONSKA-WALACH, D. (2012): Dendrogeomorphological analysis of gully erosion in different types of landscapes. Examples from Szeskie Hills and Gorce Mountains. In: Gärtner, H., Rozenberg, P., Montés, P., Bertel, O., Helle, G., Heinrich, I. (eds.): TRACE - Tree Rings in Archaeology, Potsdam, 119-126.

NYSSEN, J., POESEN, J., MOEYERSONS, J., LUYTEN, E., VEYRET PICOT, M., DECKERS, J., MITIKU, H., GOVERS, G. (2002): Impact of road building on gully erosion risk, a case study from the northern Ethiopian highlands. Earth Surface Processes and Landforms, 27, 1267-1283.

PANAGOS, P., BORRELLI, P., POESEN, J., BALLABIO, C., LUGATO, E., MEUSBURGER, K., MONTANARELLA, L., ALEWELL, C. (2015): The new assessment of soil loss by water erosion in Europe. Environmental Science and Policy, 54, 438-447.

PÁNEK, T., HRADECKÝ, J., MINÁR, J., ŠILHÁN, K. (2010): Recurrent landslides predisposed by fault-induced weathering of flysch in the Western Carpathians. In: Calcaterra, D., Parise, M. (eds.): Weathering as a Predisposing Factor to Slope Movements, 248.

POESEN, J., VANDEKERCKHOVE, L., NACHTERGAELE, J., OOSTWOUD WIJDENES, D., VERSTRAETEN, G., VAN WESEMAEL, B. (2002): Gully erosion in dryland environments. In: Bull, L.J., Kirkby, M.J. (eds.): Dryland Rivers: Hydrology and Geomorphology of Semi-arid Channels. Wiley, Chichester, U.K., 229-262.

POESEN, J., NACHTERGAELE, J., VERSTRAETEN, G., VALENTIN, C. (2003): Gully erosion and environmental change: importance and research needs. Catena, 91, 91-133.

REID, L.M., DUNE, T. (1996): Rapid Evaluation of Sediment Budgets, 1996. Catena Verlag Gmbh, Reiskirchen, Germany.

ROVÉRA, G., LOPEZ-SAEZ, J., CORONA, C., STOFFEL, M., BERGER, F. (2013): Preliminary quantification of the erosion of sandy-gravelly cliffs on Porquerolles island (Provence, France) through dendrogeomorphology, using exposed roots of Aleppo pine (Pinus halepensis Mill.). Geografia Fisica e Dinamica Quaternaria, 36, 181-187.

RUBIALES, J.M., BODOQUE, J.M., BALLESTEROS, J.A., DÍEZ-HERRERO, A. (2008): Response of Pinus sylvestris roots to sheet-erosion exposure: an anatomical approach. Natural Hazards and Earth System Sciences, 8, 223-231.

SANCHIS, M.P., TORRI, D., BORSELLI, L., POESEN, J. (2008): Climate effects on soil erodibility. Earth Surface Processes and Landforms, 33, 1082-1097.

SCHWEINGRUBER, F.H. (1978): Mikroskopische Holzanatomie. Swiss Federal Institute of Forestry Research, Birmensdorf, Switzerland.

ŠILHÁN, K. (2012a): Dendrogeomorphological analysis of evolution of slope processes on flysch rocks (the Vsetínské vrchy Mts; Czech Republic). Carpathian Journal of Earth and Environmental Sciences, 7, 39-49. 
ŠILHÁN, K. (2012b): Frequency of fast geomorphological processes in high-gradient streams: case study from the Moravskoslezsk, Beskydy Mts (Czech Republic) using dendrogeomorphic methods. Geochronometria, 39, 122-132.

ŠILHÁN, K., PÁNEK, T., DUŠEK, R., HAVLŮ, D., BRÁZDIL, R., KAŠIČKOVÁ, L., HRADECKÝ, J. (2013): The dating of bedrock landslide reactivations using dendrogeomorphic techniques: The Mazák landslide, Outer Western Carpathians (Czech Republic). Catena, 104, 1-13.

ŠILHÁN, K., PÁNEK, T., HRADECKÝ, J. (2012): Tree-ring analysis in the reconstruction of slope instabilities associated with earthquakes and precipitation (the Crimean Mountains, Ukraine). Geomorphology, 173-174, 174-184.

ŠILHÁN, K., PÁNEK, T., HRADECKÝ, J. (2013): Implication of spatial distribution of rockfall reconstructed by dendrogeomorphological methods. Natural Hazards and Earth System Sciences, 13, 1817-1826.

ŠILHÁN, K., PÁNEK, T., HRADECKÝ, J., TICHAVSKÝ, R. (2016): Polygenetic origin and surface development of the Laspi slope deformation (Crimean Mountains): the multidisciplinary approach. Zeitschrift für Geomorphologie, 60, 11-20.

ŠILHÁN, K., RUŽEK, I., BURIAN, L. (2016): Dynamics of gully side erosion: a case study using tree roots exposure data. Open Geosciences, 8, 108-116.

ŠILHÁN, K., TICHAVSKÝ, R. (2017): Snow avalanche and debris flow activity in the High Tatras Mountains: New data using dendrogeomorphic survey. Cold Regions Science and Technology, $134,45-53$.

SIRVENT, J., DESIR, G., GUTIERREZ, M., SANCHO, C., BENITO, G. (1997): Erosion rates in badland areas recorded by collectors, erosion pins and profilometer techniques (Ebro Basin, NE-Spain). Geomorphology, 18, 61-75.

STOFFEL, M. (2006): A Review of Studies Dealing with Tree Rings and Rockfall Activity: The Role of Dendrogeomorphology in Natural Hazard Research. Natural Hazards, 39, 51-70.

STOFFEL, M., CASTELLER, A., LUCKMAN, B.H., VILLALBA, R. (2012): Spatiotemporal analysis of channel wall erosion in ephemeral torrents using tree roots - An example from the Patagonian Andes. Geology, 40, 247-250.

STOFFEL, M., CORONA, C., BALLESTEROS CANOVAS, J. A., BODOQUE, J. M. (2013): Dating and quantification of erosion processes based on exposed roots. Earth-Science Reviews, 123, 18-34.

STRUNK, H. (1997): Dating of geomorphological processes using dendrogeomorphological methods. Catena, 31, 137-151.

SUN, L., WANG, X., HONG, J. (2014): Response of anatomical structures in tree roots to an erosion event on the southeastern Tibetan Plateau. Geomorphology, 204, 317-624.

TICHAVSKÝ, R., ŠILHÁN, K. (2015): Dendrogeomorphic approaches for identifying the probable occurrence of debris flows and related torrential processes in steep headwater catchments: The Hrubý Jeseník Mountains, Czech Republic. Geomorphology, 246, 445-457.

TRAPPMANN, D., CORONA, C., STOFFEL, M. (2013): Rolling stones and tree rings: a state of research on dendrogeomorphic reconstructions of rockfall. Progress in Physical Geography, 37, 701-716.

VALENTIN, C., POESEN, J., LI, Y. (2005): Gully erosion: Impacts, factors and control. Catena, 63, 132-153.

VANDEKERCKHOVE, L., MUYS, B., POESEN, J., DE WEERDT, B., COPE, N. (2001): A method for dendrochronological assessment of medium-term gully erosion rates. Catena, 45, 123-161.

VANDEKERCKHOVE, L., POESEN, J., GOVERS, G. (2003): Medium-term gully headcut retreat rates in Southeast Spain determined from aerial photographs and ground measurements. Catena, 50, 329-352. 
VANMAERCKE, M., POESEN, J., VAN MELE, B., DEMUZERE, M., BRUYNSEELS, A., GOLOSOV, V., RODIRGUES BEZERRA, J. F., BOLYSOV, S., DVINSKIH, A., FRANKL, A., FUSEINA, Y., TEIXEIRA GUERRA, A. J., HAREGEWEYN, N., IONITA, I., IMWANGANA, F. M., MOEYERSONS, J., MOSHE, I., SAMANI, A. N., NIACSU, L., NYSSEN, J., OTSUKI, Y., RADOANE, M., RYSIN, I., RYZHOV, Y. V., YERMOLAEV, O. (2016): How fast do gully headcuts retreat? Earth-Science Reviews, 154, 336-355.

VANNOPPEN, W., VANMAERCKE, M., DE BAETS, S., POESEN, J. (2015): A review of the mechanical effects of plant roots on concentrated flow erosion rates. Earth-Science Reviews, 150, 666-678.

VIAS (2005): Time Table. Installation and instruction manual. Ver. 2.1, Vienna Institute of Archaeological Science, Vienna.

VOICULESCU, M., ONACA, A. (2013): Snow avalanche assessment in the Sinaia ski area (Bucegi Mountains, Southern Carpathians) using the dendrogeomorphology method. Area, $45,109-122$.

WASSON, R. J., CAITCHEON, G., MURRAY, A. S., MCCULLOCH, M., QUADE, J. (2002): Sourcing sediment using multiple tracers in the catchment of Lake Argyle, northwestern Australia. Environmental Management, 29, 634-646.

\section{ACKNOWLEDGEMENT}

English language was reviewed by American Journal Experts service. 